\title{
Penurunan Tekanan Intraokular Pascabedah Katarak pada Kelompok Sudut Bilik Mata Depan Tertutup dan Terbuka
}

\author{
Rakhma Indria Hapsari, Andika Prahasta, Sutarya Enus \\ Departemen Ilmu Kesehatan Mata, Fakultas Kedokteran Universitas Padjadjaran-Rumah Sakit Mata \\ Cicendo Bandung
}

\begin{abstract}
Abstrak
Penebalan lensa kristalina pada katarak senilis mengakibatkan hambatan pada jalur aliran akuos. Pascabedah katarak terjadi peningkatan kedalaman bilik mata depan (BMD) yang memiliki korelasi positif dengan pelebaran sudut BMD serta penurunan tekanan intraokular (TIO). Tujuan penelitian untuk menganalisis perbedaan penurunan TIO pascabedah katarak pada kelompok sudut BMD tertutup dan terbuka. Penelitian ini menggunakan desain prepost test, untuk membandingkan penurunan TIO pascabedah katarak fakoemulsifikasi pada 26 mata dari 26 orang penderita, yang dibagi menjadi kelompok sudut BMD tertutup dan terbuka masing-masing berjumlah 13 mata. Tempat penelitian Rumah Sakit Mata Cicendo Bandung periode Maret-Juni 2012. Pengambilan data berdasarkan urutan datang penderita yang direncanakan operasi katarak fakoemulsifikasi. Penilaian sudut bilik mata depan prabedah dilakukan menggunakan lensa gonio Sussman 4-mirror. Tekanan intraokular pascabedah diukur saat pemantauan minggu ketiga pascabedah. Penilaian TIO pra dan pascabedah dilakukan menggunakan alat ukur tonometri aplanasi Goldmann. Analisis statistik dilakukan menggunakan uji t. Hasil menunjukkan perbedaan penurunan TIO secara bermakna lebih besar pada kelompok sudut BMD tertutup $(19,6 \%)$ dibandingkan dengan kelompok sudut BMD terbuka $(11,3 \%)$ dengan nilai $p=0,022$. Simpulan, perbedaan penurunan TIO pascabedah katarak fakoemulsifikasi lebih besar pada kelompok sudut BMD tertutup dibandingkan dengan kelompok sudut BMD terbuka. [MKB. 2013;45(1):56-61]
\end{abstract}

Kata kunci: Gonioskopi, katarak senilis, pascabedah fakoemulsifikasi, sudut bilik mata depan, tekanan intraokular

\section{Intraocular Pressure Reduction after Cataract Surgery between Groups with Angle-Closure and Open-Angle Anterior Chamber}

\begin{abstract}
Increased crystalline lens thickness in senile cataract causing resistance to aqueous humor outflow. Increased anterior chamber depth had a positive correlation with the widening of the anterior chamber angle and decreased of intraocular pressure (IOP) after cataract extraction. The purpose of this study was to compare IOP reduction after cataract surgery between angle-closure and open-angle group. This pre-post test design study was to compare IOP after phacoemulsification cataract surgery in 26 eyes of 26 patients divided into angle-closure and open-angle groups consisting of 13 eyes each. The study was conducted in Cicendo Eye Hospital Bandung in period of March until June 2012. Patients who planned to have phacoemulsification cataract surgery were recruited consecutively. The anterior chamber angle was measured before surgery using Sussman 4-mirror goniolens. The intraocular pressure were measured before and three weeks after surgery using Goldmann aplanation tonometer. Statistical analysis was done using t test. The results indicated that IOP reduction was statistically significant greater in the angle-closure group (19.6\%) compared with open-angle group $(11.3 \%)$ with $p=0.022$. In conclusion, IOP reduction after phacoemulsification cataract surgery was greater in the angle-closure group compared with openangle group. [MKB. 2013;45(1):56-61]
\end{abstract}

Key words: Anterior chamber angle, gonioscopy, intraocular pressure, phacoemulsification surgery, senile cataract

\footnotetext{
Korespondensi: Rakhma Indria Hapsari, dr., Sp.M., M.Kes, Departemen Ilmu Kesehatan Mata Fakultas Kedokteran Universitas Padjadjaran-Rumah Sakit Mata Cicendo Bandung, jalan Cicendo No. 4 Bandung 40117, mobile 081399481980 , e-mail rakhma.indria@gmail.com
} 


\section{Pendahuluan}

Katarak merupakan penyebab kebutaan paling banyak, pada tahun 2002 tercatat sekitar $47 \%$ penduduk dunia telah mengalami kebutaan oleh karena katarak. Menurut data terakhir dari Survei Kesehatan Indera Penglihatan dan Pendengaran tahun 1993-1996, angka kebutaan di Indonesia sebesar $1,5 \%$ dari jumlah penduduk, dan sebanyak $0,78 \%$ di antaranya disebabkan karena katarak. ${ }^{1}$ Tindakan ekstraksi katarak yang dilaporkan di India, didapatkan sekitar 3,9\% kasus merupakan katarak yang disertai dengan glaukoma sekunder akibat lensa. $^{2}$

Katarak senilis disebabkan oleh penambahan jumlah serabut lensa yang terus menerus seumur hidup, sehingga dapat mengakibatkan kekeruhan, penebalan, serta penambahan berat lensa. Proses penuaan mengakibatkan penambahan tebal lensa sebesar 0,75-1,1 mm dan pergerakan permukaan lensa ke arah anterior sebanyak 0,4-0,6 $\mathrm{mm}^{3}$. Pergeseran permukaan lensa ke bagian anterior ini mengakibatkan kedalaman bilik mata depan berkurang $0,04-0,6 \mathrm{~mm}^{3}{ }^{4}$ Ukuran lensa yang berubah juga mampu mengakibatkan penutupan sudut bilik mata depan. Menutupnya sudut bilik mata depan mengakibatkan hambatan pada jalur aliran akuos ditandai dengan peningkatan tekanan intraokular. $^{5}$

Tekanan intraokular yang meningkat akibat lensa dapat diturunkan, salah satu caranya dengan pembedahan ekstraksi lensa katarak. ${ }^{5}$ Ekstraksi lensa katarak disertai dengan penanaman lensa intraokular akan dapat meningkatkan kedalaman bilik mata depan, keadaan ini dapat disebabkan karena perbedaan ukuran tebal lensa intraokular yang ditanamkan lebih tipis yaitu sekitar $1 \mathrm{~mm} .^{6}$ Peningkatan laju aliran akuos akibat peningkatan kedalaman bilik mata depan menyebabkan akses humor akuos ke arah anyaman trabekular menjadi lebih lancar. Keadaan ini merupakan salah satu alasan yang mengakibatkan penurunan tekanan intraokular sesudah bedah katarak. ${ }^{7}$ Peningkatan kedalaman bilik mata depan memiliki korelasi positif dengan pelebaran sudut bilik mata depan pascabedah katarak, serta kedalaman bilik mata depan memiliki korelasi positif dengan penurunan tekanan intraokular pascabedah katarak. ${ }^{8,9} \mathrm{Hal}$ ini menimbulkan pertanyaan apakah mungkin bedah katarak tanpa terapi apapun dapat dipergunakan sebagai strategi yang efektif untuk menurunkan tekanan intraokular pada penderita tertentu. Saat ini, belum ada penelitian yang mencari perbedaan penurunan tekanan intraokular sesudah operasi katarak serta perbedaan besar sudut bilik mata depan prabedah yang dipakai sebagai prediktor penurunan tekanan intraokular.

Penelitian ini bertujuan untuk menganalisis perbedaan penurunan tekanan intraokular pascabedah katarak fakoemulsifikasi pada kelompok sudut bilik mata depan tertutup dan terbuka.

\section{Metode}

Penelitian ini merupakan pre-post test untuk menentukan perbedaan penurunan tekanan intraokular pascabedah katarak dengan menggunakan teknik fakoemulsifikasi antara penderita kelompok sudut bilik mata depan yang tertutup dan terbuka. Kriteria inklusi meliputi penderita katarak senilis yang direncanakan untuk dilaksanakan tindakan operasi katarak teknik fakoemulsifikasi disertai penanaman lensa intraokular, berusia $>45$ tahun, tekanan intraokular prabedah normal 10 sampai 21 $\mathrm{mmHg}$, serta dilakukan pemeriksaan gonioskopi prabedah. Penderita dengan panjang aksial bola mata $\geq 24 \mathrm{~mm}$ termasuk dalam kriteria eksklusi. Kriteria drop-out apabila saat pemantauan selama tiga minggu pascabedah katarak fakoemulsifikasi penderita mengalami edema kornea dan inflamasi pada bilik mata depan, lensa intraokular berada di luar kapsul lensa, serta penderita mengalami penyulit pada saat operasi, misalnya iridodialisis, perdarahan retrobulbar, prolaps vitreus, lepasnya membran descemet, perdarahan ekspulsif, dan juga nukleus terjatuh ke dalam vitreus. Penelitian ini dilaksanakan setelah ada persetujuan tertulis penderita. Penelitian ini dilaksanakan di Rumah Sakit Mata Cicendo (RSMC) Bandung, periode Maret sampai Juni 2012. Sampel berjumlah 26 mata dari 26 orang penderita, terdiri atas 13 mata kelompok sudut bilik mata depan tertutup dan 13 mata kelompok sudut bilik mata depan terbuka. Sampel dipilih sesuai urutan datang (consecutive admission) penderita katarak senilis yang akan direncanakan untuk dilakukan tindakan bedah katarak fakoemulsifikasi dengan cara penanaman lensa intraokular yang dilakukan di unit Katarak dan Bedah Refraktif Rumah Sakit Mata Cicendo Bandung.

Pemeriksaan prabedah mencakup penilaian sudut bilik mata depan yang dilaksanakan dengan menggunakan lensa gonio Sussman 4-mirror serta pengukuran tekanan intraokularnya. Pengukuran tekanan intraokular pascabedah dilakukan saat pemantauan minggu ketiga pascabedah katarak fakoemulsifikasi. Pengukuran tekanan intraokular pra dan pascabedah dilakukan mempergunakan tonometer aplanasi Goldmann berturut-turut dua kali pada mata dengan pupil kecil, pemeriksaan dilaksanakan pada siang hari dan dicatat waktu pemeriksaan. Dari dua kali pengukuran tersebut, akan diambil nilai tekanan intraokular rata-rata (dalam mmHg). Penilaian gonioskopi prabedah serta tekanan intraokular pra dan pascabedah rata- 
Tabel 1 Karakteristik Subjek Penelitian

\begin{tabular}{|c|c|c|c|}
\hline \multirow[b]{2}{*}{ Karakteristik } & \multicolumn{2}{|c|}{ Sudut Bilik Mata Depan } & \multirow[b]{2}{*}{ p * } \\
\hline & $\begin{array}{l}\text { Tertutup } \\
(\mathrm{n}=12)\end{array}$ & $\begin{array}{l}\text { Terbuka } \\
(\mathrm{n}=12)\end{array}$ & \\
\hline Usia (tahun) & & & $0,242 *)$ \\
\hline Rata-rata (SD) & $66,1(8,1)$ & $63,9(8,9)$ & \\
\hline Median & 69,5 & 66,5 & \\
\hline Rentang & $49-74$ & $48-79$ & \\
\hline TIO prabedah $(\mathrm{mmHg})$ & & & $0,093 * *)$ \\
\hline Rata-rata (SD) & $11,96(2,7)$ & $14,08(3,2)$ & \\
\hline Rentang & $8-16$ & $8-19$ & \\
\hline Jenis kelamin & & & $\left.1,0^{* * *}\right)$ \\
\hline Laki-laki & 4 & 5 & \\
\hline Perempuan & 8 & 7 & \\
\hline Mata yang dioperasi & & & $0,098 * * *)$ \\
\hline Kanan (OD) & 3 & 7 & \\
\hline Kiri (OS) & 9 & 5 & \\
\hline
\end{tabular}

Keterangan: nilai p dihitung berdasarkan *) Uji Mann-Whitney, **) uji t, ***) uji chi-kuadrat $\mathrm{TIO}=$ tekanan intraokular

$\mathrm{OD}=$ oculi dextra

$\mathrm{OS}=$ oculi sinistra

rata dilakukan oleh satu orang dokter spesialis mata di unit glaukoma RSMC.

Untuk mencari perbedaan penurunan tekanan intraokular pascabedah katarak fakoemulsifikasi kedua kelompok dipakai uji t tidak berpasangan dengan kemaknaan hasil uji bila nilai $p \leq 0,05$.

\section{Hasil}

Pemantauan minggu ketiga pascabedah katarak fakoemulsifikasi, didapatkan seorang penderita pada kelompok sudut bilik mata depan tertutup mengalami penyulit saat operasi dan satu penderita kelompok sudut bilik mata depan terbuka tidak datang untuk pemantauan pascabedah. Jumlah semua sampel pada akhir penelitian 24 mata yang terbagi menjadi 12 mata kelompok sudut bilik mata depan tertutup dan 12 mata kelompok sudut bilik mata depan terbuka.

Hasil analisis menggunakan uji t, Uji MannWhitney, serta uji chi-kuadrat memperlihatkan

Tabel 2 Perbandingan Tekanan Intraokular Pra dan Pascabedah antara Kelompok Sudut Bilik Mata Depan Tertutup dan Terbuka

\begin{tabular}{lccc}
\hline & \multicolumn{2}{c}{ Sudut Bilik Mata Depan } & \\
\cline { 2 - 3 } Tekanan Intraokular (mmHg) & $\begin{array}{c}\text { Tertutup } \\
(\mathbf{n}=\mathbf{1 2})\end{array}$ & $\begin{array}{c}\text { Terbuka } \\
(\mathbf{n}=\mathbf{1 2})\end{array}$ & 0,093 \\
\hline Prabedah (mmHg) & $11,96(2,7)$ & $14,08(3,2)$ & \\
$\quad$ Rata-rata (SD) & $8-16$ & $8-19$ & 0,011 \\
$\quad$ Rentang & & & \\
Pascabedah (mmHg) & $9,54(2,14)$ & $12,5(3,0)$ & \\
$\quad$ Rata-rata (SD) & $7-14,5$ & $6,5-17$ & 0,022 \\
Rentang & $19,6 \%$ & $11,3 \%$ & \\
$\quad$ Persentase penurunan TIO & & & \\
\hline
\end{tabular}

Keterangan: nilai $\mathrm{p}$ dihitung berdasarkan uji t 
bahwa gambaran karakteristik kedua kelompok penelitian ini tidak berbeda bermakna $(p>0,05)$, maka berdasarkan homogenitas kedua kelompok layak diperbandingkan (Tabel 1).

Hasil uji statistik menggunakan uji t dengan tingkat kemaknaan 5\% menunjukkan persentase penurunan tekanan intraokular lebih besar pada subjek kelompok sudut bilik mata depan tertutup $(19,6 \%)$ dibandingkan dengan kelompok sudut bilik mata depan terbuka $(11,3 \%)$, dengan nilai $\mathrm{p}=0,022$ (Tabel 2).

\section{Pembahasan}

Karakteristik subjek penelitian ini meliputi usia, tekanan intraokular prabedah, jenis kelamin, dan mata yang dilakukan operasi antara kelompok sudut bilik mata depan tertutup dan terbuka tidak berbeda, dengan demikian data tersebut dianggap sebagai data homogen serta dapat dibandingkan dan dianalisis lebih lanjut.

Kedalaman dan juga volume bilik mata depan akan berkurang sesuai dengan usia seseorang yang bertambah, salah satu alasanya adalah lensa yang mengalami katarak itu akan menjadi tebal dan sudut bilik mata bagian depan menyempit. ${ }^{10}$ Menurut Wu dkk, ${ }^{11}$ kelompok subjek penelitian yang berusia di bawah 60 tahun memiliki sudut dan volume bilik mata depan yang lebih kecil. Menurut Wojciechowski dkk. ${ }^{12}$ dibuktikan penebalan lensa yang mengakibatkan pendangkalan sudut bilik mata depan, hal ini terjadi pada kelompok usia di bawah 65 tahun. Penelitian ini mempergunakan kriteria inklusi subjek penelitian dengan usia $>45$ tahun untuk melihat pengaruh penyempitan sudut pada kelompok usia tersebut yang lensa kristalinanya sudah menunjukkan katarak. Hasil penelitian didapatkan usia rata-rata usia subjek penelitian dengan sudut bilik mata depan tertutup 66,1 tahun, sedangkan dengan sudut bilik mata depan terbuka 63,9 tahun (Tabel 1).

Subjek penelitian dengan sudut bilik mata depan tertutup pada perempuan lebih banyak bila dibandingkan dengan laki-laki. Keadaan ini sesuai dengan beberapa penelitian yang dilaksanakan di Asia bahwa perempuan memiliki sudut bilik mata depan yang lebih sempit dibandingkan dengan laki-laki. ${ }^{12}$ Berdasarkan artikel yang dikeluarkan oleh Medround, dinyatakan perempuan memiliki mata yang lebih kecil dibandingkan dengan lakilaki, sehingga bilik mata depan dan sudut bilik mata depan akan lebih sempit. ${ }^{13}$

Berbagai penelitiantentang penurunantekanan intraokular pascabedah telah banyak dilakukan, salah satu alasan yang menyebabkan penurunan tekanan intraokular yaitu berkurangnya hambatan aliran humor akuos. ${ }^{7}$ Penelitian ini menunjukkan penurunan tekanan intraokular yang lebih besar pada kelompok subjek penelitian dengan sudut bilik mata depan tertutup $(19,6 \%)$ dibandingkan dengan kelompok sudut bilik mata depan terbuka $(11,3 \%)$ (Tabel 2).

Rentang tekanan intraokular pascabedah pada kelompok subjek dengan sudut bilik mata depan tertutup ialah 7-14,5 mmHg dan pada kelompok subjek dengan sudut bilik mata depan terbuka yaitu $6,5-17 \mathrm{mmHg}$. Tekanan intraokular normal rata-rata pada populasi non-glaukoma sebesar 15 $\mathrm{mmHg}$. Rentang tekanan intraokular normal yaitu 10-21 mmHg, jika tekanan intraokular berkisar $<6 \mathrm{mmHg}$ keadaan ini disebut hipotensi okular. ${ }^{14}$ Kesepakatan umum menyatakan bahwa untuk keseluruhan populasi tidak ada ketentuan yang pasti pada kisaran serendah atau setinggi berapa tekanan intraokular yang dikatakan normal atau aman sebab tiap individu memiliki toleransi yang berbeda-beda. ${ }^{5}$ Penelitian ini mendapatkan nilai tekanan intraokular terendah $6,5 \mathrm{mmHg}$ belum merupakan hipotensi okular.

Berdasarkan penelitian Zhou dkk. ${ }^{15}$ terdapat perbedaan yang bermakna antara besar sudut bilik mata depan pra dan pascabedah fakoemulsifikasi dengan menggunakan alat ukur optical coherence tomography of the anterior segment (AS-OCT), akan tetapi tidak berbeda secara bermakna antara penurunan tekanan intraokular dan besar sudut bilik mata depan. Perbedaan hasil penelitian Zhou dkk. ${ }^{15}$ dengan penelitian ini, disebabkan karena bias terhadap pengambilan gambar dan besarnya sudut menggunakan AS-OCT akibat pemeriksa tunggal yang dipergunakan pada penelitian ini. Kekurangan lainnya yaitu keterbatasan penilaian sudut bilik mata depan yang hanya dilakukan pada bidang horizontal $180^{\circ}$ di kuadran nasal dan temporal. Hal yang sama juga telah dinyatakan oleh Sakata dkk. ${ }^{16}$ mengenai kekurangan penilaian sudut bilik mata depan pada kuadran superior dan inferior karena keterlibatan palpebra, serta kemungkinan bias jika menggunakan pemeriksa tunggal.

Berbeda dengan penelitian tersebut di atas, penelitian ini menggunakan alat ukur lensa gonio Sussman 4-mirror untukpenilaian sudut bilikmata depan prabedah. Pemeriksaan gonioskopi dapat melihat insersi iris secara nyata, penilaian ada tidaknya sudut bilik mata depan terbuka, struktur iris, dan struktur bilik mata depan. Friedman dan $\mathrm{He}^{17}$ menyatakan bahwa gonioskopi merupakan acuan standar saat ini untuk penilaian struktur dan konfigurasi sudut bilik mata depan. Beberapa penelitian mendapatkan bahwa alat ukur AS-OCT cenderung untuk mendeteksi sudut yang tertutup pada kebanyakan penderita dibandingkan dengan gonioskopi. ${ }^{16,18}$

Perbedaan yang ditemukan antara penemuan 
AS-OCT dan gonioskopi dapat dikaitkan dengan perbedaan penanda anatomis dan tingkat kontak iris yang dipergunakan untuk menentukan sudut tertutup. Penentuan sudut tertutup pada gambar AS-OCT apabila terdapat kontak iris dengan tepi anterior skleral spur. ${ }^{18}$ Lokasi anyaman trabekular tidak dapat ditentukan pada gambaran AS-OCT. ${ }^{18}$ Sudut terbuka pada gonioskopi apabila aposisi yang tidak mencapai tingkat posterior anyaman trabekular (PT). Penentuan suatu struktur skleral spur tidak dapat ditentukan pada sekitar $20-30 \%$ gambaran AS-OCT. Keadaan ini disebabkan oleh karena resolusi rendah pada sisi lateral gambaran AS-OCT, variasi anatomi mata, dan artefak pada gambar kelopak mata atau struktur lainnya, serta kesulitan teknis dalam hal pengambilan gambar pada beberapa kuadran. ${ }^{16}$ Keterbatasan dalam hal penilaian skleral spur pada gambaran AS-OCT tersebut dapat mengurangi keakuratan gambar yang didapat. ${ }^{19}$ Keunggulan lainnya pemeriksaan gonioskopi menggunakan lensa gonio Sussman 4-mirror ialah kemampuannya untuk melakukan pemeriksaan gonioskopi dinamik yang berguna untuk membedakan aposisi iridokornea perlekatan sinekia, serta penentuan sudut occludable atau sudut tertutup parsial. ${ }^{5}$ Dapat disimpulkan bahwa hingga saat ini gonioskopi masih menjadi acuan standar untuk penentuan struktur sudut bilik mata depan dalam penegakan diagnosis.

Pascabedah fakoemulsifikasi serta implantasi lensa intraokular, biasanya ditemukan inflamasi ringan pada bilik mata depan. Pemberian dosis rendah kortikosteroid topikal atau antiinflamasi nonsteroid dapat menurunkan reaksi peradangan setelah 1-2 minggu pascabedah dan menghilang sepenuhnya setelah 2-3 minggu. ${ }^{20}$ Pengambilan data primer untuk tekanan intraokular pascabedah dilakukan saat pemantauan 3 minggu pascabedah guna menghindari bias pada penelitian ini.

Keterbatasan penelitian ini adalah kesulitan peneliti untuk melakukan pemeriksaan tekanan intraokular pra dan pascabedah pada waktu yang sama, sehingga untuk menghindari bias variasi diurnal peneliti melakukan pemeriksaan tekanan intraokular pascabedah pada kisaran waktu yang sama yaitu siang hari seperti pemeriksaan tekanan intraokular prabedah. Pemeriksaan gonioskopi pascabedah dapat berguna untuk menilai sudut bilik mata depan pascabedah sebagai pembanding dengan sudut bilik mata depan prabedah, tetapi pada penelitian ini tidak dilakukan.

Simpulan, kelompok sudut bilik mata depan tertutup menunjukkan hasil penurunan tekanan intraokular pascabedah katarak fakoemulsifikasi lebih besar bila dibandingkan dengan kelompok sudut bilik mata depan terbuka serta disarankan pemeriksaan gonioskopi prabedah pada semua penderita katarak dan perlu penelitian lebih lanjut untuk membandingkan pengaruh bedah katarak pada tekanan penurunan intraokular penderita sudut tertutup primer dan sekunder.

\section{Daftar Pustaka}

1. World Health Organization. Blindness: vision 2020-the global initiative for the elimination of avoidable blindness 2008 [diunduh 17 Oktober 2011]. Tersedia dari: http://www. who.int/blindness/Vision2020_report.pdf.

2. Qamar AR. Phacomorphic glaucoma: an easy approach. Pak J Ophthalmol. 2007;23(2):779.

3. Tarongoy P, Ho CL, Walton DS. Angleclosure glaucoma: the role of the lens in the pathogenesis, prevention, and treatment. Surv Ophthalmol. 2009;54(2):211-25.

4. Chen Y, Bao YZ, Pei XT. Morphologic changes in the anterior chamber in patients with cortical or nuclear age-related cataract. J Cataract Refract Surg. 2011;37(1):77-82.

5. Cioffi GA, Durcan FJ, Girkin CA, Gross RL, Netland PA, Samples JR, dkk. Glaucoma. basic and clinical science course. San Francisco: LEO; 2008.

6. Visualizing eye surgery [database on the Internet]. Medical Design. 2010 [diunduh 20 Februari 2012]. Tersedia dari: http://medicaldesign.com/engineeringprototyping/software/fea-brings-prostheticlens-201011/index1.html.

7. Mathalone $N$, Hyams $M$, Neiman $S$, Buckman G, Hod Y, Grever O. Long-term intraocular pressure control after clear corneal phacoemulsification in glaucoma patients. J Cataract Refract Surg. 2005;31(3):479-83.

8. Kim M, Park KH, Kim TW, Kim DM. Changes in anterior chamber configuration after cataract surgery as measured by anterior segment optical coherence tomography. Korean J Ophthalmol. 2011;25(2):77-83.

9. Issa SA, Pacheco J, Mahmood U, Nolan J, Beatty S. A novel index for predicting intraocular pressure reduction following cataract surgery. $\mathrm{Br} \quad \mathrm{J}$ Ophthalmol. 2005;89(5):543-6.

10. Schacknow PN, Samples JR. The glaucoma book: a practical, evidence-based approach to patient care. New York: Springer; 2010 [diunduh 15 Mei 2011]. Tersedia dari: http:// books.google.co.id/books?id=53P1yuXGbkC\&pg=PA335\&lpg=PA335\&dq=Schackno $\mathrm{W}+\mathrm{PN}+$ Samples $+\mathrm{JR}$.

11. Wu RY, Nongpiur ME, He MG, Sakata LM, Friedman DS, Chan YH, dkk. Association of narrow angles with anterior chamber 
area and volume measured with anterior segment optical coherence tomography. Arch Ophthalmol. 2011;129(5):569-74.

12. Wojciechowski R, Congdon N, Anninger W, Broman A. Teo. Age, gender, biometry, refractive error, and the anterior chamber angle among Alaskan Eskimos. Ophthalmology. 2003;110(2):365-75.

13. Kwon YH, Fingert JH, Greenie EC. Risk factors for primary angle-closure glaucoma (pacg). Medrounds [serial on the Internet] 2006 [diunduh 20 Februari 2012]. Tersedia dari: http://www.medrounds.org/glaucomaguide/2006/06/section-5-b-risk-factors-forprimary.html.

14. Watson PG, Jovanovik-Pandova L. Prolonged intraocular hypotension: would cilliary tissue transplantation help. Eye. 2009;23(10):191625.

15. Zhou AW, Giroux J, Mao AJ, Hutnik CML. Can preoperative anterior chamber angle width predict magnitude of intraocular pressure change after cataract surgery? Can J Ophthalmol. 2010;45(2):149-53.

16. Sakata LM, Lavanya R, Friedman DS, Aung
HT, Gao H, Kumar RS, dkk. Comparison of gonioscopy and anterior segment ocular coherence tomography in detecting angle closure in different quadrant of the anterior chamber angle. Ophthalmology. 2007;115(5):769-74.

17. Friedman DS, He M. Anterior chamber angle assesment techniques. Surv Ophthalmol. 2008;53(3):250-73.

18. Nolan WP, See JL, Chew PT, Friedman DS, Smith SD, Radhakrishnan S, dkk. Detection of primary angle closure using anterior segment optical coherence tomography in Asian eyes. Ophthalmology. 2007;114(1):33-9.

19. Goldsmith JA, Li Y, Chalita MR, Westphal V, Patil CA, Rollins AM, dkk. Anterior chamber width measurement by high-speed optical coherence tomography. Ophthalmology. 2005;112(2):238-44.

20. Raizman MB. Prolonged intraocular inflammation. Dalam: Chang DF, BissenMiyajima H, Fine H, Gimbel HV, Koch DD, Lane SS, dkk, penyunting. Cataract surgery. Edisi ke-3. Duxbury: Elsevier Inc; 2010. hlm. 687-94. 